\title{
The speciation of chemical elements in water and their possible impact on human health
}

\author{
Svetlana Mazukhina ${ }^{1}$, Pavel Tereshchenko ${ }^{2, *}$, Svetlana Drogobuzhskaya ${ }^{3}$ and Vladimir \\ Pozhilenko ${ }^{4}$ \\ ${ }^{1}$ Institute of North Industrial Ecology Problems - Subdivision of the Federal Research Centre "Kola \\ Science Centre of the Russian Academy of Sciences" (INEP KSC RAS); 184209, Murmansk region, \\ Apatity, Akademgorodok, 14a, Russia \\ ${ }^{2}$ Research Centre for Human Adaptation in the Arctic - Branch of the Federal Research Centre "Kola \\ Science Centre of the Russian Academy of Sciences" (RCHAA KSC RAS); 184209, Murmansk \\ region, Apatity, Akademgorodok, 41a, Russia \\ ${ }^{3}$ Tananaev Institute of Chemistry - Subdivision of the Federal Research Centre "Kola Science Centre \\ of the Russian Academy of Sciences" (ICT KSC RAS); 184209, Murmansk region, Apatity, \\ Akademgorodok, 26a, Russia \\ ${ }^{4}$ Geologikal Institute - Subdivision of the Federal Research Centre "Kola Science Centre of the \\ Russian Academy of Sciences" (GI FRC KSC RAS); 184209, Murmansk region, Apatity, \\ Akademgorodok, 10a, Russia
}

\begin{abstract}
The speciation of chemical elements in groundwaters of Apatity Kirovsky district may affect their bioavailability and toxicity. A complete hydrochemical analysis showed measurable concentrations of uranium, molybdenum, silver, barium, nickel, vanadium, aluminum, and lead, which contributed to a growing database of the chemical compositions of groundwater. Physical and chemical models showed that the vital elements calcium, sodium, potassium, magnesium and sulfate ion are in chemical forms that are favorable for human health $\left(\mathrm{Ca}^{2+}, \mathrm{Na}^{+}, \mathrm{K}^{+}\right.$, $\mathrm{Mg}^{2+}, \mathrm{SO}_{4}{ }^{2-}$ ). Forms of migration of carcinogenic or toxic elements (nickel, barium, vanadium, strontium, aluminum, lead) are among the most toxic $\left(\mathrm{Ni}^{2+}, \mathrm{Ba}^{2+}, \mathrm{Sr}^{2+}\right)$ and remain so at the temperatures studied $+3,+25$, $+37^{\circ} \mathrm{C}$. One of the most insidious effects of inorganic compounds of lead, barium and strontium is the ability to replace calcium in bones isomorphically, nickel in the form of free ions $\left(\mathrm{Ni}^{2+}\right)$ is 2 times more toxic than its complex compounds with inorganic and organic ligands. The results of this research can be useful in the fields of geochemistry, hydrology, ecology and medicine.
\end{abstract}

\section{Introduction}

Hydrogeology has seen major advances in recent years, and these result from emphasizing the relevance of studying interaction of water with rocks and other surrounding components [1]. This approach corresponds to the ideas of J.-B. Lamarck and V.I. Vernadsky [2].

*Corresponding author: tereshchenko_pash@mail.ru 
Water is the singular chemical compound that determines the possibility of life on Earth. The daily human consumption of drinking water averages about 2 liters, and the total water consumption and use per capita in developed countries is 150 to 300 liters per day. The water content in the body of a newborn is $97 \%$, decreasing with age to $70-80 \%$, in particular, the brain contains about $85 \%$ water. The most important quality of water, which is the main solvent, is its chemical composition [3].

Understanding the chemical evolution of waters as a result of natural or anthropogenic influence involves scientists of the whole world. Particular attention is paid to solutes derived from the interaction of water with rocks, of which the most interesting system is "water-aluminosilicates" [1]. Freshwater reserves are a strategic factor in the development of the Russian economy [4]. At the same time, the chemical composition of water has the most important influence on the health of the global population [5-7].

The Murmansk region has a well developed metallurgical and mining and processing industry, leading to pollution of local and regional water supplies. Although the toxic elements do not exceed drinking-water standards, measurable amounts of these elements exist in the water supplies. The toxic effect of elements on the human body is determined by their chemical speciation, the number and composition of compounds, as well as the individual characteristics of the body [7]. Therefore, an important task is to study the chemical forms of elements in the aquatic environment, since it is they that influence the uptake and bioavailability of pollutants and their toxicity to living organisms [8-9]. According to A.V. Skalny vital elements include cations: $\mathrm{Ca}^{2+}, \mathrm{Na}^{+}, \mathrm{K}^{+}, \mathrm{Mg}^{2+}, \mathrm{Mn}^{2+}, \mathrm{Zn}^{2+}$, $\mathrm{Fe}^{2+}, \mathrm{Cu}^{2+}$ and $\mathrm{Co}^{2+}$, as well as anions in single element form and in the form of complex anionic groups: $\mathrm{Cl}^{-}, \mathrm{I}^{-}, \mathrm{PO}_{4}{ }^{3-}, \mathrm{SO}_{4}{ }^{2-}, \mathrm{MoO}_{4}{ }^{2-}$ and $\mathrm{SeO}_{3}{ }^{2-}$ [6]. Currently, the quality of drinking water is assessed in comparison with maximim permissible concentration of elements or compounds according to state sanitary standards (San PiN 2.1.4.1074-01) [10], but [11] indicated the need to take into account the ratio of some other elements in solution. The purpose of this work is to assess the change in chemical forms of elements from one of the springs of Apatity depending on temperature using physical and chemical modeling (software package "Selektor") [12].

\section{Results and Discussion}

Over the years, the authors have investigated the chemical evolution of waters in the context of water-rock interactions with the rocks of Fennoscandia (the Hibinsky massif) and related formations. These waters are drinking water sources for residents of the Apatity-Kirovsk district.

The concentration of chemical forms of elements $(\mathrm{mg} / \mathrm{l})$, calculated with software package "Selektor", depending on the temperature regime are presented in Table 1 and in Figure 1.

Table 1. The concentration of chemical forms of elements ( $\mathrm{mg} / \mathrm{l}, \mathrm{P}=1 \mathrm{bar}$ ).

\begin{tabular}{|l|c|c|c|}
\hline \multirow{2}{*}{$\begin{array}{c}\text { Chemical } \\
\text { forms of } \\
\text { elements }\end{array}$} & \multicolumn{3}{|c|}{ Temperature } \\
\cline { 2 - 4 } & Sampling & Room & Human body \\
\cline { 2 - 4 } & $+3^{\circ} \mathrm{C}$ & $+25^{\circ} \mathrm{C}$ & $+37^{\circ} \mathrm{C}$ \\
\hline $\mathrm{Al}(\mathrm{OH})_{2}{ }^{+}$ & $1.58 \cdot 10^{-5}$ & $6.55 \cdot 10^{-6}$ & $3.96 \cdot 10^{-6}$ \\
\hline $\mathrm{Al}(\mathrm{OH})_{2} \mathrm{~F}$ & $1.43 \cdot 10^{-4}$ & $6.62 \cdot 10^{-5}$ & $4.42 \cdot 10^{-5}$ \\
\hline $\mathrm{AlO}_{2}^{-}$ & $6.96 \cdot 10^{-2}$ & $8.15 \cdot 10^{-2}$ & $8.96 \cdot 10^{-2}$ \\
\hline $\mathrm{HAlO}_{2}$ & $3.63 \cdot 10^{-3}$ & $2.20 \cdot 10^{-3}$ & $1.76 \cdot 10^{-3}$ \\
\hline $\mathrm{Al}(\mathrm{OH})^{2+}$ & $4.67 \cdot 10^{-7}$ & $4.36 \cdot 10^{-8}$ & $1.23 \cdot 10^{-8}$ \\
\hline
\end{tabular}




\begin{tabular}{|l|c|c|c|}
\hline $\mathrm{Al}(\mathrm{OH})_{3}$ & $2.53 \cdot 10^{-3}$ & $2.01 \cdot 10^{-3}$ & $1.79 \cdot 10^{-3}$ \\
\hline $\mathrm{Al}(\mathrm{OH})_{4}^{-}$ & $1.19 \cdot 10^{-1}$ & $1.03 \cdot 10^{-1}$ & $9.07 \cdot 10^{-2}$ \\
\hline $\mathrm{Zn}^{2+}$ & $1.62 \cdot 10^{-1}$ & $7.97 \cdot 10^{-2}$ & $4.05 \cdot 10^{-2}$ \\
\hline $\mathrm{ZnCl}^{+}$ & $2.95 \cdot 10^{-7}$ & $5.33 \cdot 10^{-7}$ & $5.46 \cdot 10^{-7}$ \\
\hline $\mathrm{ZnOH}^{+}$ & $4.95 \cdot 10^{-2}$ & $1.52 \cdot 10^{-1}$ & $2.01 \cdot 10^{-1}$ \\
\hline $\mathrm{ZnO}$ & $2.23 \cdot 10^{-4}$ & $1.27 \cdot 10^{-3}$ & $2.35 \cdot 10^{-3}$ \\
\hline $\mathrm{HZnO}_{2}{ }^{-}$ & $4.66 \cdot 10^{-6}$ & $2.56 \cdot 10^{-5}$ & $4.97 \cdot 10^{-5}$ \\
\hline $\mathrm{ZnF}^{+}$ & $4.72 \cdot 10^{-6}$ & $2.30 \cdot 10^{-6}$ & $1.26 \cdot 10^{-6}$ \\
\hline $\mathrm{Ni}^{2+}$ & $9.63 \cdot 10^{-3}$ & $9.62 \cdot 10^{-3}$ & $9.60 \cdot 10^{-3}$ \\
\hline $\mathrm{Ca}^{2+}$ & 21.6 & 21.5 & 21.4 \\
\hline $\mathrm{CaOH}^{+}$ & $6.95 \cdot 10^{-5}$ & $4.74 \cdot 10^{-4}$ & $1.27 \cdot 10^{-3}$ \\
\hline $\mathrm{CaCO}_{3}$ & $4.53 \cdot 10^{-1}$ & $6.87 \cdot 10^{-1}$ & $8.72 \cdot 10^{-1}$ \\
\hline${\mathrm{Ca}\left(\mathrm{HCO}_{3}\right)^{+}}^{+}$ & $8.04 \cdot 10^{-1}$ & $7.38 \cdot 10^{-1}$ & $7.69 \cdot 10^{-1}$ \\
\hline $\mathrm{CaHSiO}_{3}{ }^{+}$ & $1.31 \cdot 10^{-2}$ & $1.50 \cdot 10^{-2}$ & $1.83 \cdot 10^{-2}$ \\
\hline $\mathrm{CaF}^{+}$ & $2.25 \cdot 10^{-4}$ & $2.42 \cdot 10^{-4}$ & $2.70 \cdot 10^{-4}$ \\
\hline $\mathrm{CaSO}_{4}$ & $5.71 \cdot 10^{-1}$ & $6.22 \cdot 10^{-1}$ & $6.86 \cdot 10^{-1}$ \\
\hline $\mathrm{Pb}^{2+}$ & $3.17 \cdot 10^{-6}$ & $6.01 \cdot 10^{-6}$ & $7.89 \cdot 10^{-6}$ \\
\hline $\mathrm{PbOH}^{+}$ & $4.44 \cdot 10^{-4}$ & $4.40 \cdot 10^{-4}$ & $4.36 \cdot 10^{-4}$ \\
\hline $\mathrm{HgO}^{2+}$ & $1.80 \cdot 10^{-4}$ & $1.80 \cdot 10^{-4}$ & $1.80 \cdot 10^{-4}$ \\
\hline $\mathrm{Ba}^{2+}$ & $4.75 \cdot 10^{-3}$ & $4.75 \cdot 10^{-3}$ & $4.74 \cdot 10^{-3}$ \\
\hline $\mathrm{BaCO}_{3}$ & $1.16 \cdot 10^{-5}$ & $1.81 \cdot 10^{-5}$ & $2.35 \cdot 10^{-5}$ \\
\hline $\mathrm{Sr}^{2+}$ & $5.83 \cdot 10^{-2}$ & $5.77 \cdot 10^{-2}$ & $5.71 \cdot 10^{-2}$ \\
\hline $\mathrm{SrHCO}_{3}{ }^{+}$ & $1.21 \cdot 10^{-3}$ & $2.03 \cdot 10^{-3}$ & $2.83 \cdot 10^{-3}$ \\
\hline
\end{tabular}

Lead $\left(\right.$ as $\left.\mathrm{Pb}^{2+}\right)$ is one of the strongest toxicants for living organisms. Inorganic lead compounds may act as enzyme inhibitors, and long-term consumption of water, even with a low content of this metal may be one of the causes of acute and chronic diseases. Zinc - an element necessary for humans and animals - migrates in six different forms, with the chemical form prevailing at low temperatures $\mathrm{Zn}^{2+}$, but with increasing temperature $\mathrm{ZnOH}^{+}$ species becomes more dominant.

Nickel is a potentially carcinogenic element. It is believed that its free ions $\left(\mathrm{Ni}^{2+}\right)$ are 2 times more toxic than its complex compounds with inorganic and organic ligands [13]. Its chemical form of migration does not change with temperature, i.e. it remains toxic. The water also contains barium and strontium ions, the predominant forms of migration of which $\mathrm{Ba}^{2+}$ and $\mathrm{Sr}^{2+}$ do not change with temperature. Note that barium, strontium, and lead accumulate in the same organs as calcium [14].

From the results obtained (Fig. 1), it can be seen that:

- the initial water $\mathrm{pH}$ decreases with increasing temperature;

- the forms of copper change;

- $\mathrm{HPO}_{4}{ }^{2-}$ is always the dominant form of phosphorus, with $\mathrm{HPO}_{4}{ }^{3-}$ several orders of magnitude less;

- $\mathrm{Fe}(\mathrm{OH})_{3}$ is the dominant form of iron. 

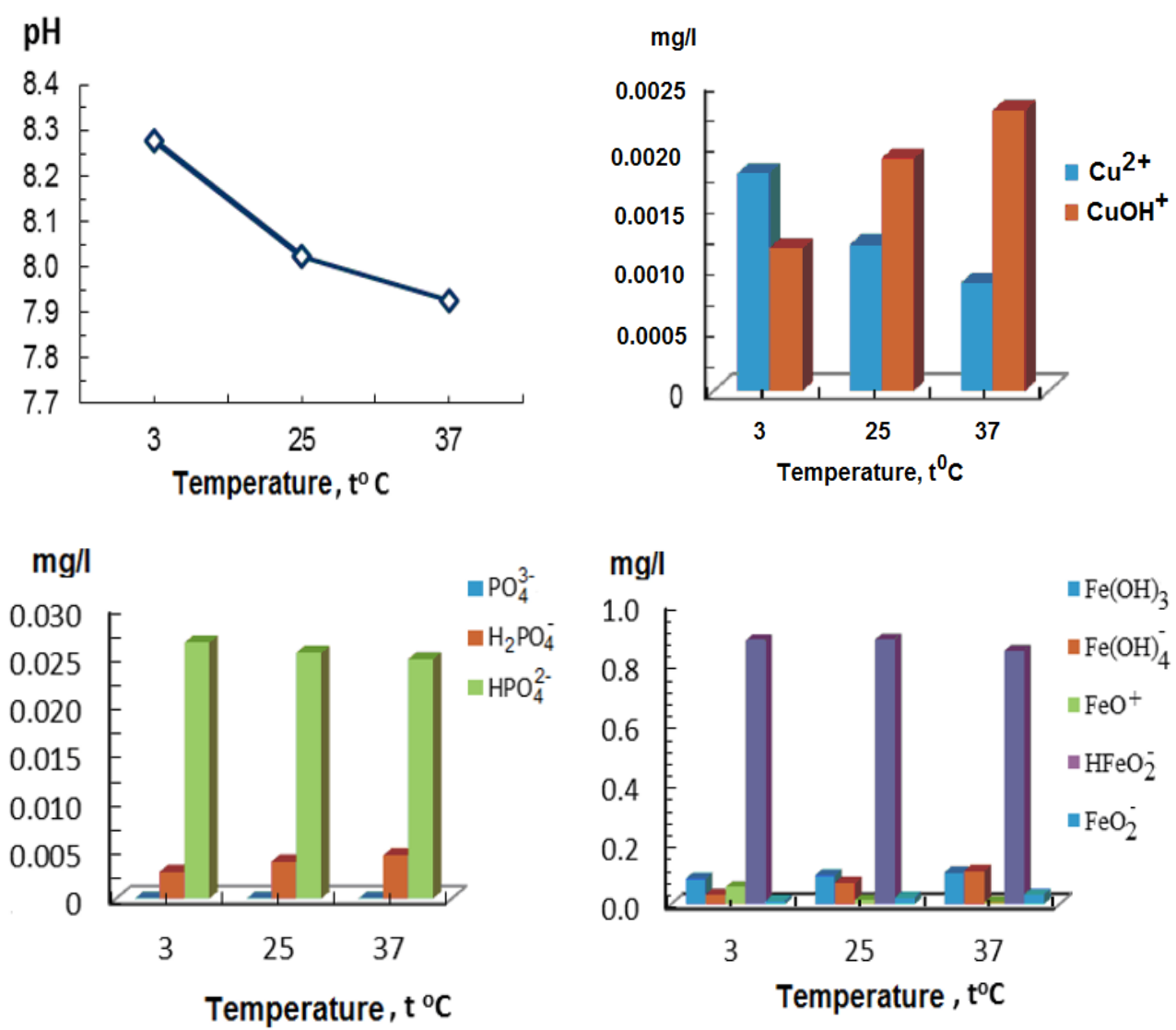

Fig. 1. Changes in $\mathrm{pH}$, copper, phosphorus and iron ions depending on temperature.

The study of the water-rocks system showed that the waters of spring are saturated with the following minerals: $\mathrm{CaCO}_{3}{ }^{-}-0.03 ; \mathrm{SiO}_{2}-98.57$; muscovite - 0.27; $\mathrm{MnO}_{2}-0.15$; $\mathrm{FeO}(\mathrm{OH})-0.72$; apatite $-0.03 ; \mathrm{Zn}_{2} \mathrm{SiO}_{4}-0.22 \%$. These results show that as temperature conditions change, some elements change their chemical form (copper, zinc), some will precipitate (iron, manganese), and some will remain in their toxic form (Table 1). Thus, it was shown that with the help of precision methods of analysis and mathematical modeling, it is possible not only to estimate the elemental composition of water and to track the chemical forms of elements, but also to evaluate their transformation with changing physical conditions (temperature, etc.).

The study was carried out with the financial support of RFBR and the Ministry of Education and Science of the Murmansk region within the framework of the scientific project 17-45-510640 "Geochemical assessment of groundwater in the Khibiny massif (age and identification of the origin of groundwater, chemical composition, forms of migration of elements)".

\section{References}

1. S. L. Shvartsev Geoecology. Engineering geology. Hydrogeology. Geocryology, 3, 272-279 (2013)

2. S. L. Shvartsev Bulletin of the Russian Academy of Sciences, 82, 3, 242-251 (2012) 
3. G. Blanco, A. Blanco Medical Biochemistry. (Academic Press, 2017)

4. V. I. Danilov-Danilyan RAS Bulletin (M.), 77, 2 (2007)

5. L. I. Elpiner, I.S. Zektser Water resources, 26, 4 389-396 (1999)

6. A. V. Skalny Chemical elements in human physiology and ecology. (Mir, Moscow, 2004)

7. T. Moiseenko, V. Megorsky, N. Gashkina, L. Kudryavtseva Water resources, 37, 2, 199-208 (2010)

8. C. T. Driscoll Environ. Health Perspectives, 63, 93-104 (1985)

9. P. N. Linnik, V. Zhezherya Water resources, 40, 2,165-178 (2013)

10. SanPiN 2.1.4.1074-01 Drinking water. https://znaytovar.ru/gost/2/SanPiN_214107401_Pitevaya_voda.html

11. S. M. Kravchenko Geoecology, 1, 30-36 (1998)

12. K. V. Chudnenko Akadem. publishing house "Geo" (2010)

13. P. N. Linnik, B.I. Nabivanets Forms of migration of metals in a fresh surface water. (Leningrad, Gidrometeoizdat, 1986)

14. A. I. Perelman Geokhimiya. Edition 2.(The higher school, Moscow, 1989) 